\title{
CHAPTER 17 \\ PROVISION OF ECONOMIC SECURITY \\ OF CONSTRUCTION INDUSTRY ENTERPRISES: INDUSTRIAL FEATURES AND INDICATOR SYSTEM
}

\section{Fisunenko P. A.}

\section{Introduction}

In the context of economic and political instability, imperfect reforms and the security situation in Ukraine, construction companies operate in a complex environment characterized by constant dynamics and a large number of external and internal threats.

The construction industry is one of the main drivers of economic development in the country. But its functioning is characterized by a number of specific features that are reflected in the activities of industry economic entities and cause some difficulties in identifying threats to construction enterprises and ensuring their economic security.

The assessment of economic security in general, and in construction in particular, is being investigated by V. M. Heiets, N. M. Bohdan, T. H. Vasyltsiv, O. B. Zhykhor, T. V. Momot, M. O. Kyzym, T. S. Klebanova, A. O. Kushniruk, A. B. Melnykov, S. P. Mishchenko, O. O. Molodid, Yu. V. Pynda, I. V. Piriatinska, S. A. Terenchuk, O. V. Tofaniuk, I. O. Filatova, O. V. Fedosova, O. I. Cherniak, M. V. Chorna and others. At the same time, there is an imperfection of approaches to considering ways of ensuring the economic security of construction enterprises, taking into account specific types of threats affecting the economic security of construction industry enterprises.

Modern approaches to the effective functioning of construction companies, regardless of their specialization, should be based on maintaining an adequate level of economic security. Ensuring the safety of a construction company is a complex process of shaping the conditions and mechanisms for the stable operation of a particular entity, which is influenced by a large number of external and internal factors. Identification of these factors that generate threats and development of a system of indicators characterizing the level of economic security of enterprises in the construction industry is a topical and urgent task of modern economic science and practice. 


\subsection{State of construction industry enterprises as a basis for economic security}

The state of construction and its prospects are determined by the general state of the Ukrainian economy. The main problem of the development of construction still is the increase in the cost of work due to the rise in price of the main components of construction. In order to maintain the level of profitability, construction companies are forced to increase the cost of works and services, which adversely affects the dynamics of demand from customers as a result. The loss of construction reduces its investment attractiveness. As of January-September 2019, the number of unprofitable companies exceeded $21 \%$ of the total number of enterprises in the industry ${ }^{1}$. The slow growth of long-term lending also restricted opportunities for increased financing for investment projects. The main priority areas of structural reorganization of construction will be the expansion, reconstruction, re-profiling and technical re-equipment of existing objects.

According to experts, the construction economy, as well as the entire economic mechanism of the country, is in a constant state of serious change. The field of construction is quite important and relevant, since its development depends on many factors, among which are:

- people's provision by housing, cultural, educational and scientific institutions;

- availability of industrial and commercial facilities;

- organization and carrying out of general and specialized works on construction and reconstruction of industrial enterprises and constructions, housing construction, objects of cultural and household purpose;

- timely implementation of the listed objects etc.

The construction complex is a collection of industries, industries and organizations characterized by close established economic, organizational, technical and technological ties in obtaining the end result, i. e., ensuring the production of fixed assets of the national economy. The final result is organizationally combining construction organizations and industries, as well as organizations of other industries into a single whole ${ }^{2}$.

\footnotetext{
1 Derzhavnyi komitet statystyky Ukrainy [State Statistics Committee of Ukraine]. URL: www.ukrstat.gov.ua

${ }^{2}$ Safonov YU.M., Kravets V.R., Oliukha V.H. (2014). Ekonomiko-pravovi osnovy kapitalnoho budivnytstva : navch. posib [Economic and Legal Foundations of Capital Construction: tutorial. tool] Kyiv : Tsentr uchbovoi literatury, 239 p.
} 
Based on the logic of development of construction enterprises, it can be argued that any research in this field is clearly expressed sectoral and regional character, as it is evidenced by world experience. Therefore, for the prosperity of industries and regions, the regional authorities set the task of pursuing an active urban policy of the region and the industry, creating favourable conditions for the formation of regional construction complex, its composition and structure - both technological and by ownership of the means of production. These measures, their development and their use in the construction are of paramount importance for the region.

The introduction of new construction methods (prefabricated structures, upgrading of the technical level, application of the current method of entering works, etc.) will significantly improve the efficiency of construction production technologies and adjust the cost. Construction organizations independently formulate their goals and objectives, develop a strategy and tactics of their development, seek the financial resources they need, form a labour collective, deal with the acquisition of funds and objects of work, solve many organizational issues in creating an organizational management structure, etc. That is, construction organizations conduct their activities independently, and state influence on their economic and functional behaviour can be mediated indirectly with mandatory legislative support ${ }^{3}$.

The relationship between the state of the construction industry and the development of the national economy can be demonstrated by looking at the key performance indicators of these enterprises.

Thus, according to the State Statistics Service of Ukraine, the volume of manufactured construction products (construction works performed) by Ukrainian enterprises amounted to UAH 26.5 billion in January-March 2019. Information about previous periods is shown in Figyre 1.

As wee can see, the construction industry is showing a tendency to increase the volume of construction works, which should have a positive impact on the state of construction enterprises and the state of the national economy.

\footnotetext{
${ }^{3}$ Fedorenko V.H., Tuhai A.M., Hoiko A.F., Dzhabeilo V.B. (2007). Kontseptsiia stratehii rozvytku budivelnoho kompleksu Ukrainy na period do 2015 roku [Concept of strategy of development of construction complex of Ukraine for the period up to 2015]. Ekonomika ta derzhava, no. 1, pp. 3-7.
} 


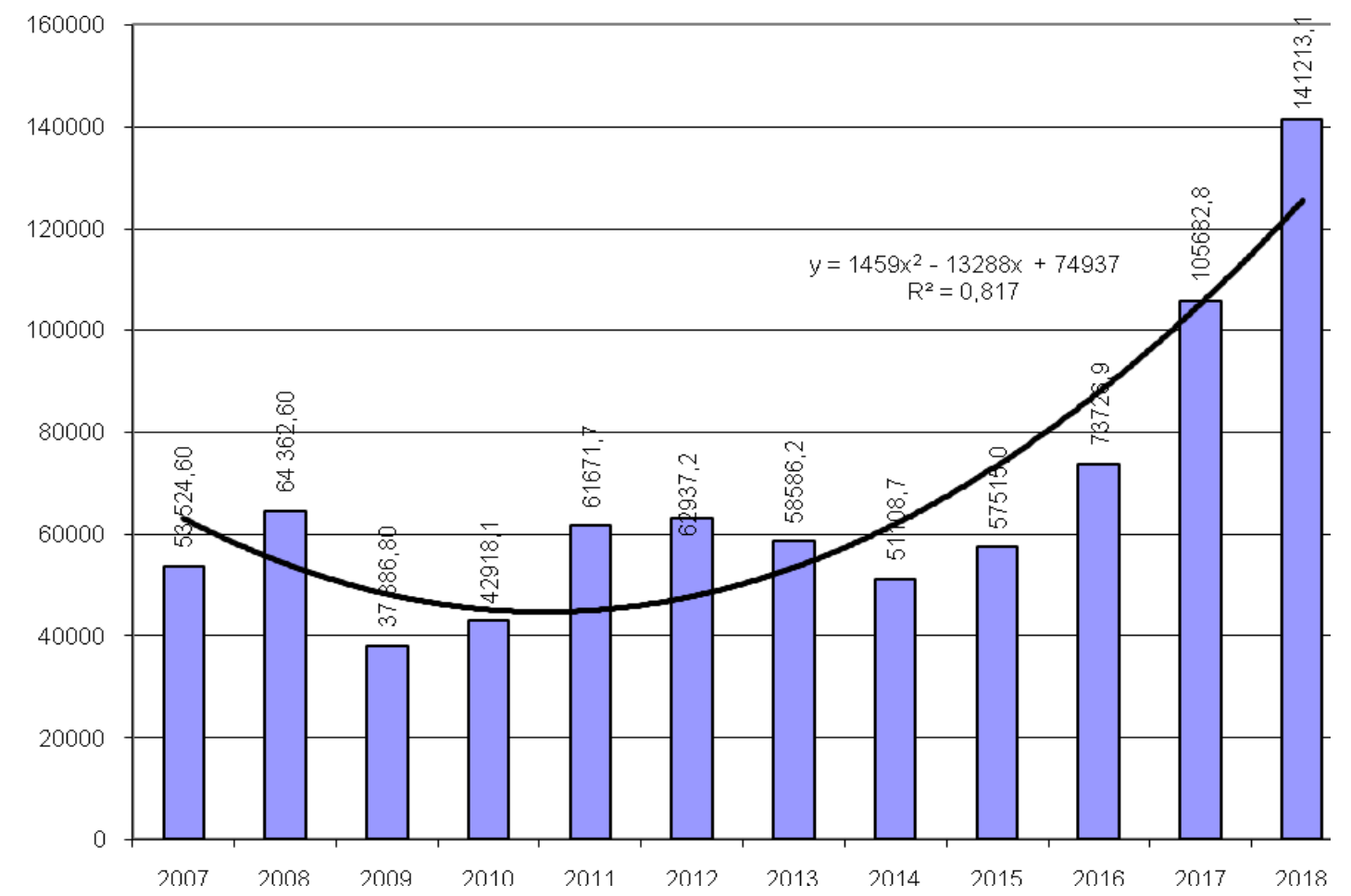

Figure 1. The volume of completed construction works for the period 2007-2018, UAH billion

High growth rates of fixed capital investment are needed to significantly upgrade the fixed assets, which should be implemented in the coming years, as the moral and physical depreciation of fixed capital in Ukraine in recent decades has reached a level where only accelerated growth in the production of productive industries can provide a significant increase production and growth of living standards. The main source of financing for the manufacturing sector of the economy is the equity of enterprises, so to stimulate their investment, it is necessary to strengthen both the state's participation in the investment process and the enterprises. In conditions of stimulation by the state of investments into the economy of the country and annual increase of the volume of investments sustainable economic growth is possible ${ }^{4}$. Regardless of whether or not the above conditions are fulfilled, the problem of economic security of enterprises is one of the most important. In the case of its achievement, enterprises have the opportunity to effectively realize

\footnotetext{
${ }^{4}$ Orlovska Yu.V., Fisunenko P.A., Levchenko V.F. (2013). Analiz stanu ta tendentsii rozvytku budivelnykh pidpryiemstv u konteksti doslidzhennia yikh ekonomichnoi bezpeky [Analysis of the state and tendencies of development of construction enterprises in the context of the study of their economic security]. Teoretychni $i$ praktychni aspekty ekonomiky ta intelektualnoi vlasnosti: Zbirnyk naukovykh prats. Mariupol: DVNZ «PDTU», Vyp. 1, T. 1, pp. 248-252.
} 
their production and economic potential, and when creating more favourable conditions enterprises can realize fully the strategic goals.

As the construction industry is one of the key sectors of the economy, the efficiency of construction companies is an indicator of the economic development and economic security of the country. It will be interesting to consider the results of the calculation of the level of economic security in general and by individual components, conducted by the Ministry for Development of Economy, Trade and Agriculture of Ukraine in accordance with the Methodological Recommendations for the Calculation of the Level of Economic Security of Ukraine from 29.10.2013 No $1277^{5}$ (Table 1).

Table 1

Economic security level: integral and separate components, \%

\begin{tabular}{|c|c|c|c|c|c|c|c|c|c|c|}
\hline \multirow[b]{2}{*}{ Year } & \multicolumn{9}{|c|}{ Components of economic security (ES) } & \multirow[b]{2}{*}{ 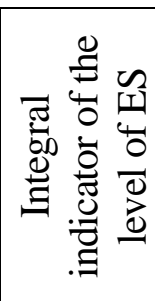 } \\
\hline & 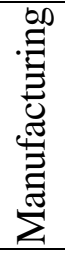 & 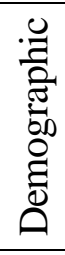 & $\begin{array}{l}\text { 总 } \\
\text { 童 }\end{array}$ & 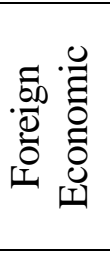 & 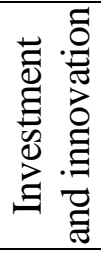 & 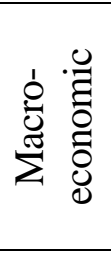 & $\begin{array}{l}\overline{0} \\
\overline{0}\end{array}$ & $\begin{array}{l}\bar{\pi} \\
\overline{8} \\
\tilde{n}\end{array}$ & 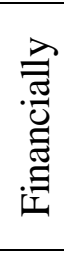 & \\
\hline 2007 & 61 & 41 & 32 & 40 & 43 & 48 & 85 & 58 & 64 & 52 \\
\hline 2008 & 56 & 44 & 34 & 36 & 43 & 38 & 83 & 56 & 51 & 48 \\
\hline 2009 & 52 & 46 & 31 & 38 & 34 & 44 & 84 & 58 & 42 & 46 \\
\hline 2010 & 50 & 47 & 35 & 41 & 35 & 38 & 90 & 57 & 44 & 47 \\
\hline 2011 & 55 & 56 & 32 & 36 & 36 & 48 & 92 & 59 & 47 & 50 \\
\hline 2012 & 49 & 45 & 34 & 29 & 37 & 38 & 93 & 64 & 46 & 47 \\
\hline 2013 & 49 & 46 & 39 & 35 & 35 & 39 & 86 & 62 & 50 & 48 \\
\hline 2014 & 51 & 45 & 47 & 35 & 30 & 33 & 94 & 57 & 36 & 45 \\
\hline 2015 & 47 & 43 & 45 & 37 & 35 & 31 & 92 & 55 & 35 & 44 \\
\hline 2016 & 57 & 46 & 58 & 40 & 30 & 36 & 92 & 56 & 38 & 48 \\
\hline 2017 & 58 & 40 & 54 & 40 & 33 & 34 & 91 & 59 & 40 & 48 \\
\hline $\begin{array}{l}\text { I half- } \\
\text { year of } \\
2018\end{array}$ & 60 & 41 & 54 & 40 & 30 & 41 & 90 & 56 & 43 & 49 \\
\hline
\end{tabular}

As the integral indicator of the level of economic security of Ukraine is in the range $40 \div 52 \%$, the situation is characterized as a dangerous level of economic security.

If we compare the integral indicator of the level of economic security and the volume of construction work performed (Figure 2), we

5 Metodychni rekomendatsii shchodo rozrakhunku rivnia ekonomichnoi bezpeky Ukrainy vid 29.10.2013 roku № 1277 / M-vo ekonomichnoho rozvytku i torhivli Ukrainy. URL: https://zakon.rada.gov.ua/rada/show/v1277731-13/stru (accessed 18.09.2019). 
can see some common trends, in particular, a decrease in these indicators from 2012 to 2014 and their growth from 2016 to 2018.

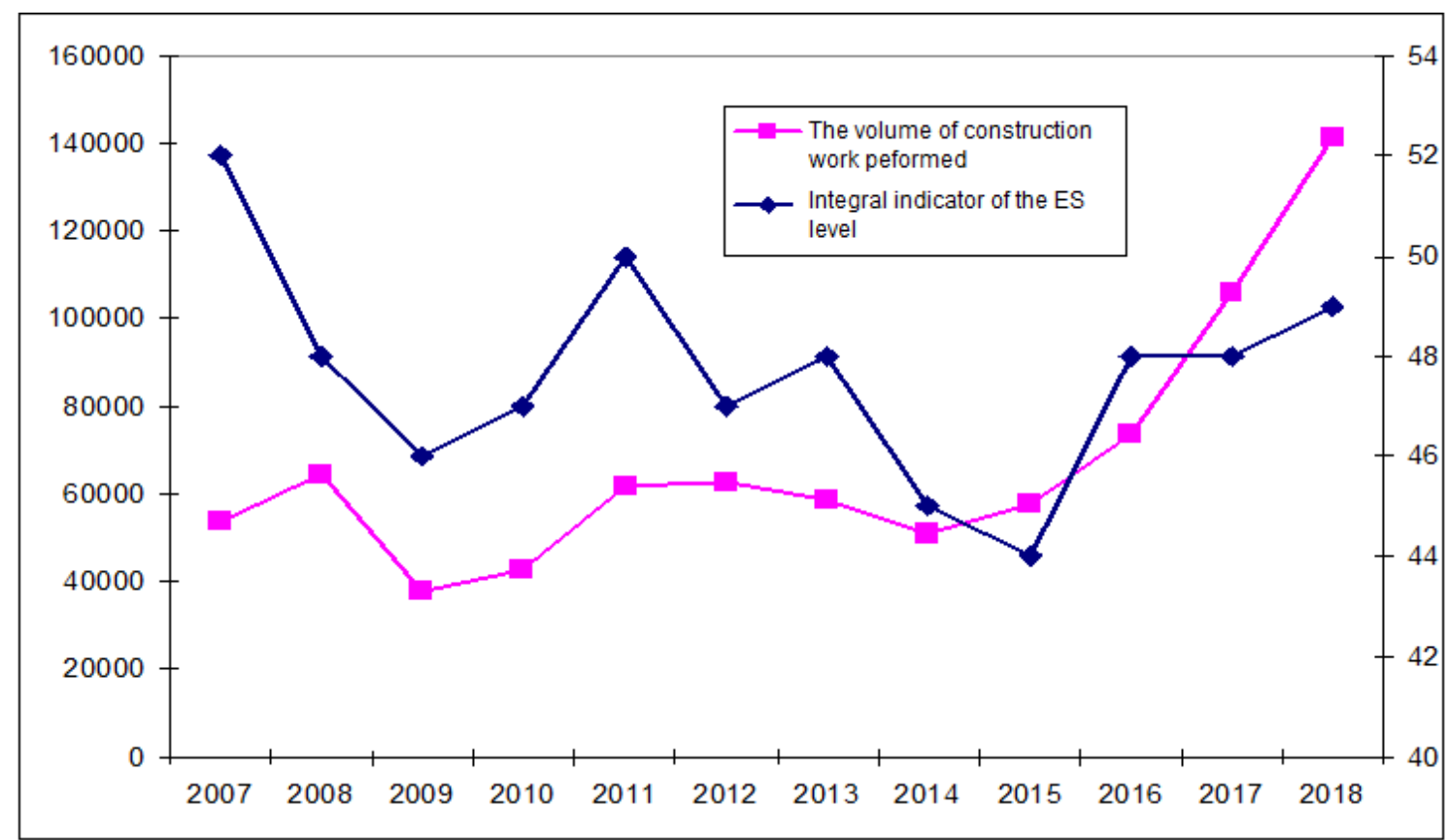

Figure 2. Comparison of the volume of construction works performed and the integrated indicator of the level of economic security

In order to ensure effective functioning, the modern enterprise of the construction industry needs not only to constantly monitor the level of economic security, but to respond promptly to changes in the environment, the emergence of potential and real threats, taking into account the peculiarities of socio-economic development, its tendencies and prospects. Formation of a system of effective economic and organizational measures to counteract their possible negative impact and timely response to them is aimed at providing maximum opportunities for realizing the economic interests of enterprises on the one hand, and ensuring a sufficient level of their economic security, in particular with regard to external threats. That is, prompt response of construction companies to changes in the environment, counteracting the negative impact from the outside, developing effective tools, must take into account a wide range of factors of socio-economic development of the country, as well as industry and regional specificity, based on a certain sufficient level of economic security.

Based on the analysis of the state of the construction industry, we can conclude that the development of construction enterprises in modern 
conditions to overcome the effects of crisis phenomena is possible only on the basis of effective management of their economic security.

\subsection{Features of ensuring the economic security of construction industry enterprises}

According to Economic Code of Ukraine, ensuring the proper level of economic security is to maximize profit, but from the point of view of the enterprise its main purpose is to provide guarantees of stable and maximally effective functioning at the present stage of management and to provide high potential for development in the future ${ }^{6}$. Based on the main purpose of the enterprise, the main functional goals of the enterprise are formed: ensuring high efficiency of work, financial stability and independence of the enterprise; ensuring technological independence of the enterprise; achievement of high competitiveness of the technical potential of the enterprise; achievement of high level of qualification of staff and their intellectual potential; ensuring effective management at the enterprise; minimizing the destructive impact of the production and economic activity of the enterprise on the environment; patent purity of all aspects of the enterprise; ensuring the protection of the information field, trade secrets and achieving the required level of information support for the work of all units of the enterprise; effective organization of safety of the personnel of the enterprise, its capital and property, and also commercial interests ${ }^{7}$. The main and functional goals determine the formation of the necessary structure-forming elements and the general scheme of organization of economic security. As it was mentioned earlier, the economic security of an enterprise is influenced by factors both internal and external. Functional components of economic security are set of basic directions of its economic security, significantly different from each other in content ${ }^{8}$.

The construction industry is one of the most important industries on which the efficiency of the entire economic system of the country depends. The importance of this industry for the economy of any country can be explained as follows: capital construction creates a large number of jobs and uses the products of many branches of the national economy. Production of building materials and related equipment, machine-

\footnotetext{
${ }^{6}$ Hospodarskyi kodeks Ukrainy vid 16.01.2003 № 436-IV [Commercial Code of Ukraine dated 16.01.2003 № 436-IV]. URL: http://zakon1.rada.gov.ua/laws/show/436-15

${ }^{7}$ Molodid O.O. (2009). Kharakterystyka zahroz ekonomichnoi bezpeky budivelnoho pidpryiemstva [Characterization of threats to the economic security of a construction company]. Teoriia $i$ praktyka budivnytstva, no. 5, pp. 54-58.

${ }^{8}$ Ekonomika pidpryiemstva : pidruch. / za red. S. F. Pokropyvnoho. Kyiv : KNEU, 2001. 526 p.
} 
building industry, metallurgy and metalworking, petrochemicals, woodworking industry, transport, energy, etc. are developing with the development of the construction industry. Also, construction more than other sectors of the economy contributes to the development of small and medium-sized businesses. The development of the construction industry inevitably causes economic growth in the country and the solution of many social problems. At the present stage, it is quite difficult to talk about any competitiveness of this industry. At the regional level, the tendency of the supremacy of the construction organizations of the central districts and large cities in connection with their considerable capacities and investment attractiveness is clearly observed, at the global level the construction industry of Ukraine is far behind due to the lack of necessary financial and organizational transformations ${ }^{9}$.

In order to identify the threats to construction enterprises, a number of factors affecting these enterprises must be taken into account. First of all, the nature of the construction work often does not allow us to determine in advance the final cost of the work on the object, which creates a number of threats:

- competition in the order market (unfair competition in all its manifestations);

- monopolization of the market by large construction companies; orders;

- corruption relations in the distribution of state and municipal

- internal fraud.

Construction is a technically complex process that creates the following types of specific threats to economic security:

- causing damage to the object of construction, equipment, damage to inventory;

- personal injury (occupational injuries);

- threat of a product defect (including hidden ones) for works performed by subcontractors, as well as the low quality of used construction materials;

- threat of a product defect caused by the poor quality of work of the project organizations, as well as the general contractors.

Even a slight product defect or lack of technology can lead to serious financial losses for a construction company.

\footnotetext{
${ }^{9}$ Byba V.V., Hatash V.S. (2013). Stan ta perspektyvy rozvytku budivelnoi haluzi Ukrainy [State and prospects of development of construction industry of Ukraine]. Haluzeve mashynobuduvannia, budivnytstvo, Vyp. 4(39), T. 2. pp. 83-89.
} 
Workplace safety and personnel issues in the economic security system should be given greater attention. Many construction business entities involve a number of employees, usually construction workers, without proper legal registration. As a rule, their salaries are not officially paid; the procedure for issuing it to unformed employees is not guaranteed and remains a matter of employer integrity. The salary of such employees is substantially smaller than that of full-time employees. Such employees are usually not qualified enough. Thus, the problem of informal personnel carries a number of threats to the economic security of the enterprise:

- reducing the quality of work performed;

- increasing the level of injuries;

- needing for illegal financial transactions to obtain officially unaccounted cash in cash for payment, with all financial and other risks inherent in such transactions.

It is noteworthy that almost all of these threats occur both when using unformed employees, the construction company itself, and its general contractor, subcontractor.

Seasonality and arrhythmicity, which is a feature of construction work, increase non-production costs, creating the following threats:

- weather risk factor;

- economic loss caused by planning errors;

- aggravation of the staffing problem: the company is forced to either have a larger staff of employees with forced downtime during periods of low load, or to attract additional employees during periods of high workload.

The remoteness and territorial separation of objects creates the following threats to the economic security of construction companies:

- reducing the level of control of the construction process on the site;

- increasing transport risks;

- theft of technically tangible assets at object warehouses and objects.

It is possible to summarize the composition of the factors affecting the economic security of construction industry enterprises (Figure 3).

The above listed threats cause the existence of a number of sectoral features of economic security of construction enterprises, which must be taken into account by economic security specialists. In order for construction organizations to be able to do this, they need to set up their 
own economic security services or involve specialists from companies that specialize in providing economic security services to businesses.

\section{Factors affecting the economic security of construction industry} enterprises

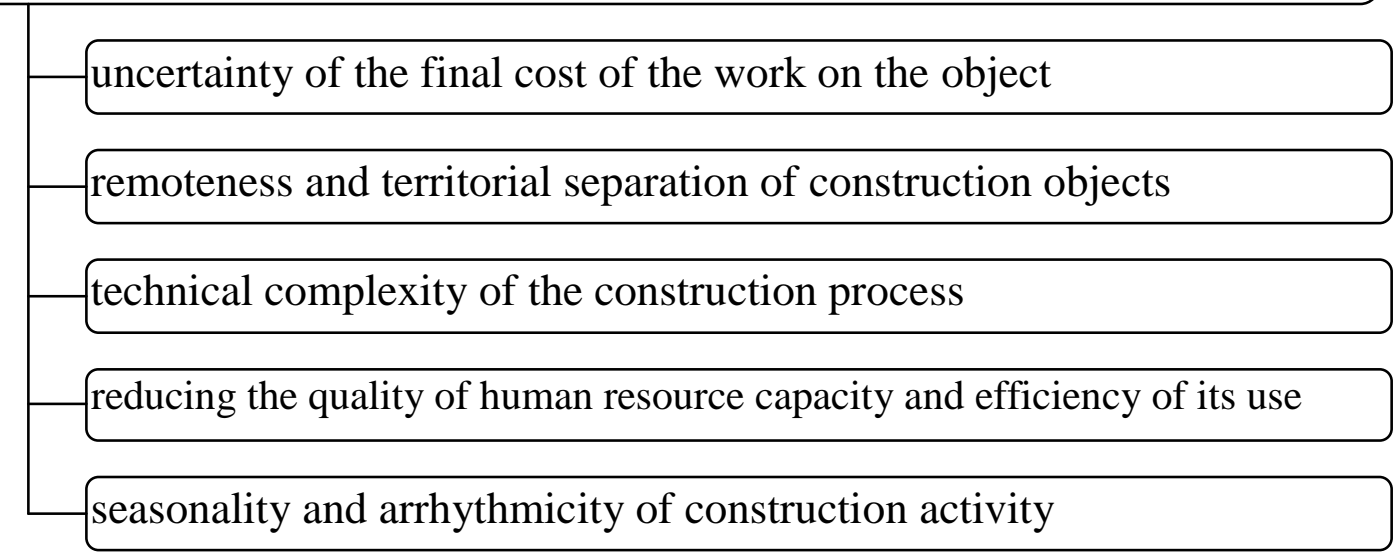

\section{Figure 3. Classification of factors affecting the economic security of construction industry enterprises}

Large construction companies have their own security services in one way or another. The drawbacks of their work are that such units cannot evaluate and analyze the situation in the industry as a whole, the maximum they are doing now is evaluate one or the other contractor with whom the project work is planned. Specialized companies providing economic security services have a more global nature of information coverage. In addition, specialized companies for economic security have a large staff of specialists who have the knowledge and practical skills in the organization of business, accounting, and economy as a whole. They analyze all the documentation of the various services of the enterprise, while the security services at the enterprise (and their organization is often reduced to hiring a lawyer who only has to protect the interests of the company in the courts) are unable to do so. But it is better not to bring the case to the court, to resolve controversial and problematic issues in the process of work. But this is often not possible for the lawyer of the company, and sometimes for its management. In today's environment, only that company can stay in the market for a long time and have competitive advantages, in which the costs and results of activities will be fully determined by the level of management efficiency, volume and quality of work of each unit and each employee. Therefore, when the company is invited by specialists of specialized 
companies for providing economic security services, they should first of all get acquainted with its structure, services, etc. External experts help to check that the organizational units are rationally organized and, if necessary, to help them properly coordinate their work across the enterprise.

Thus, the specificity of construction enterprises allows concluding the complexity and ambiguity of determining the economic security of enterprises in the construction industry. As the construction industry is one of the key sectors of the economy, the efficiency of construction companies is an indicator of economic development. To ensure the effective functioning of the modern enterprise of the construction industry, it is necessary not only to constantly monitor the level of economic security, but to respond promptly to changes in the environment, the emergence of potential and real threats, taking into account the peculiarities of social and economic development, its tendencies and prospects. Formation of a system of effective economic and organizational measures to counteract their possible negative impact and timely response to them is aimed at providing maximum opportunities for realizing the economic interests of enterprises on the one hand, and ensuring a sufficient level of their economic security, in particular with respect to external threats. That is, prompt response of construction companies to changes in the environment, counteracting the negative impact from the outside, the development of effective tools, must take into account a wide range of factors of socio-economic development of the country, as well as industry and regional specificity, based on a certain sufficient level of economic security.

\subsection{Analysis of the system of indicators of economic security of enterprises of the construction industry}

At the present stage of economic development, construction industry enterprises have suffered significant losses due to lack of financing, freezing of investment activity, outdated material and technical base and inability to prevent, neutralize internal and external threats and quickly adapt to environmental instability. That is why the development and functioning of business objects depends to a large extent on a reliable, high-quality and sound system of economic security of the enterprise, based on relevant indicators of its level assessment.

Despite the great interest of domestic and foreign scientists and practitioners in the problems of economic security assessment, it 
should be noted that the existing developments mainly focus on various aspects of national and regional security and, to a lesser extent, on the economic security of enterprises. Efficiency of functioning and existence of enterprises directly depends on the degree of protection of their economic interests.

For construction companies, the assessment of economic security is important, first of all, because their potential is a significant factor for development, a guarantor of economic growth and support of the country's economic independence ${ }^{10}$.

The attention to the research of theoretical problems of estimation of the level of economic security of enterprises and the system of indicators was paid by such economists as I. A. Blank, T. H. Vasyltsiv, S. B. Dovbnia, N. Yu. Hychova, M. M. Zatserklianyi, S. V. Kavun, O. A. Kyrychenko, M. O. Kyzym, T. S. Klebanova, A. H. Temchenko, N. O. Podluzhna, O. V. Cherniak, S. M. Shkarlet, O. F. Melnykov, R. A. Rudenskyi, N. P. Kapustin and others.

In their works, the authors consider the problems of managing the economic security of the enterprise as a whole and in its constituent elements. Considerable attention is paid to substantiating the essence of economic security, its elements, the need for a comprehensive study of this phenomenon, approaches to assessment are offered.

The well-known concept of economic security of the enterprise includes financial, intellectual, personnel, technical, technological, political, environmental, information and power components ${ }^{11}$. To calculate the level of economic security of enterprises a system of indicators is used. It can be divided into four groups (Figure 4).

Based on the study of the works of scientists, let us consider the list of indicators for each group in more detail.

According to experts, the state of security of the enterprise in the financial sphere characterizes the financial security of the enterprise. This component shows how effectively corporate resources are used. The main indicators used in assessing this component of economic security are:

- absolute liquidity ratio is the ratio of absolutely liquid assets to an entity's current liabilities. The ratio shows how much of an enterprise's debt can be paid immediately;

\footnotetext{
${ }^{10}$ Vasyltsiv T.H. (2008). Ekonomichna bezpeka pidpryiemnytstva Ukrainy: stratehiia ta mekhanizmy zmitsnennia: Monohrafiia. Lviv: Aral, 384 p.

${ }^{11}$ Ekonomika pidpryiemstva : pidruch. / za red. S. F. Pokropyvnoho. Kyiv : KNEU, 2001. 526 p.
} 


\section{Groups of indicators for assessing the level of economic security of construction industry enterprises}

Financial security indicators

Personnel security indicators

Technical and technological safety indicators

Information, political and legal, environmental, power security indicators

\section{Figure 4. Groups of indicators for assessing the level of economic security of the enterprise}

- quick liquidity ratio. It reflects the company's current payment ability to pay its current liabilities, provided that payments to customers are timely. It is calculated as the ratio of current assets of high (urgent) liquidity to short-term liabilities;

- overall liquidity ratio is the ratio of current assets to short-term liabilities;

- autonomy (financial independence) ratio. It shows the proportion of equity in the total amount of funds advanced in its activities. It is calculated by dividing the equity by the balance sheet of the enterprise;

- financial stability ratio. It characterizes the ability of the enterprise to attract external sources of financing. It is calculated by dividing the cost of borrowed funds by equity;

- financial leverage ratio is determined by the ratio of debt to equity. This ratio reflects the structure of capital: the greater its value, the greater the share of borrowed capital, the greater the risk and dependence on external sources of financing;

- current assets ratio. This is an indicator of the number of turnover of current assets of the enterprise for a certain period. It is found by dividing the proceeds of all activities of the enterprise (net income) by the current assets of the enterprise;

- fixed assets ratio;

- return on assets. It characterizes the efficiency of use of all available assets of the enterprise and is found as the net income ratio of the enterprise to the average value of assets; 
- return on margin. It characterizes the efficiency of costs for its production. It is determined by the ratio of profit on sales for a certain period (net profit) to the cost of sales;

- return on sales. It characterizes the efficiency of costs for production and sales. It is defined as the ratio of the profit from the sale of products for a certain period (gross income) to the total (net) income of the enterprise.

The state of security of the enterprise in the technical and technological sphere characterizes the degree of conformity of the applied technology and technology applied at the enterprise to the modern world analogues with regard to the optimization of the cost of resources. It is often suggested to consider the following indicators:

- fixed asset turnover that reflects the efficiency of the use of fixed capital and characterizes the amount of products that account for one hryvnia of the value of fixed assets. Striving for this indicator to the maximum under other equal conditions is regarded as a positive phenomenon in the economy of use of fixed assets of the enterprise. Fixed-asset turnover is calculated as the ratio of the value of fixed assets to the volume of sales;

- capital-labour ratio is an indicator of the equipment of labour with basic means of production. It is determined by the ratio of the average annual book value of fixed productive assets to the average number of employees;

- fixed asset disposal ratio is defined as the ratio of the value of the fixed assets retired in the accounting period to the initial value of the fixed assets;

- fixed asset upgrade ratio is calculated as the ratio of the value of fixed assets acquired in the accounting period to the value of fixed assets at the beginning of the accounting period;

- capital intensity is the inverse of fixed asset turnover. This indicator also reflects the efficiency of fixed assets. It shows what part of the cost of fixed assets is UAH 1 of sales. Indicator of capital intensity is calculated as the ratio of the value of fixed assets to the volume of output;

- return on fixed assets. This indicator informs on the return of fixed assets of the enterprise on profit, on how much profitably used fixed assets during the analyzed time.

The security situation of the company in the personnel sphere is characterized by the following indicators: 
- staffing ratio is determined by the ratio of the actual number of employees to the number of employees in accordance with the staff list;

- labour turnover characterizes employee loyalty. It is calculated by the ratio of the number of dismissed employees for all reasons to the average number;

- labour productivity (workforce productivity) is an indicator of employees' work activity. It is calculated by the ratio of output to the average number of employees.

- intelligence level of employees is the ratio of the number of highly skilled workers to the average number of employees.

The security status of an organization in the information, political and legal, environmental, power fields is characterized by the following indicators:

- the level of information component of economic security may be determined by the proportion of incomplete, inaccurate and contradictory information used in the management decision-making process, as well as the cost of information used by the enterprise in the course of its activity. Typically, information productivity ratio is calculated as the ratio of output to the cost of acquiring information resources;

- political and legal security is determined by the level of legal protection of the interests of the enterprise in contractual and other business documents, the level of observance of the legal rights of the enterprise and its employees, the level of preservation of commercially important information, the level of observance of the rules of patent law. The following indicators can be used: payment discipline ratio, legal services quality ratio;

- environmental component is characterized by compliance with environmental standards of technology and production, minimizing the losses of the enterprise from environmental pollution. Environmental pollution factor is calculated as an element of environmental safety (the ratio of the amount of ecotaxes to the costs of the enterprise);

- power component of economic security can be characterized by the amount of physical and moral actions directed at individuals, especially the managers and leading specialists of the enterprise, with the aim of harming their health (physical and psychological), as well as reputation and material well-being, which is a threat to normal activity of the enterprise. Also actions that damage the property of the enterprise, threaten to reduce the value of its assets and loss of economic independence (access to confidential information of the enterprise, 
industrial espionage, misinformation, destruction of information, etc.) should be evaluated for this component. For this component, the factor of protection of property and personnel of the enterprise is calculated as the ratio of the costs of business protection to the amount of net income of the enterprise.

The main purpose of forming a system of indicators for assessing the level of economic security of the enterprise is to ensure the effective functioning and use of available resources, to ensure a certain level of working life of staff and quality of economic processes of the enterprise, as well as to constantly stimulate the increase of existing potential and its stable development. In most cases, each element of an enterprise's economic security system can exist only because it receives support or some properties from other elements, that is, it is constantly interconnected and interdependent with all elements of the system.

Based on the study of the existing system of indicators, we can conclude that the problem of determining the level of economic security of the enterprise is poorly structuring, which has a pronounced hierarchical, multi-level structure. When calculating the level of economic security, there is a difficulty in selecting the most appropriate indicators for each component and avoiding duplication of indicators. Thus, it is necessary to improve the existing system of indicators by eliminating "duplicate indicators" and creating a basic system of economic security for construction enterprises to further form the system of integrated assessment for a more effective assessment of economic security.

\section{CONCLUSIONS}

The research allowed us to draw the following conclusions.

The condition of the enterprises of the construction industry, as one of the main branches of the economy of Ukraine, is an indicator of the development of the economy and economic security of the country. Comparison of the dynamics of the integral indicator of the level of economic security, calculated by the Ministry for Development of Economy, Trade and Agriculture of Ukraine, and the volume of construction works performed (according to the State Statistics Service of Ukraine), allowed to establish certain common trends over the analyzed period of time (from 2007 to 2018), which may testify to the relationship of these phenomena.

The established specificity of the activity of the enterprises of the construction industry revealed the complexity and ambiguity of the 
process of determining and ensuring their economic security. In order to ensure proper economic security, a modern enterprise must constantly monitor its level of economic security; respond promptly to changes in the external environment, occurrence of potential and real threats, taking into account the peculiarities of the functioning of the industry and specific threats identified.

The study of the existing system of indicators for assessing the level of economic security of construction industry enterprises has identified a number of problems, including the presence of a large number of indicators that sometimes duplicate each other, the difficulty in selecting the most relevant indicators and preparing an information base for calculating them. There is a need to improve the system of indicators by eliminating "duplicate indicators" and creating a basic system of economic security of construction enterprises to further form the system of integrated assessment.

\section{SUMMARY}

The article is devoted to the consideration of industry peculiarities and system of indicators of ensuring the economic security of construction industry enterprises. The state of the construction industry enterprises as a basis for ensuring economic security has been investigated. Common tendencies in the dynamics of the indicator of the level of economic security of Ukraine and the volume of construction works are established.

Specific factors that affect the economic security of construction industry enterprises have been identified. The identified threats cause the existence of a number of sectoral features of economic security of construction enterprises, which should be taken into account by economic security specialists.

The existing system of indicators for assessing the level of economic security of construction industry enterprises has been investigated. The task of improvement of this system for the further formation of the integral estimation of level of economic security of the enterprises of the construction industry is set.

\section{REFERENCES}

1. Byba V.V., Hatash V.S. (2013). Stan ta perspektyvy rozvytku budivelnoi haluzi Ukrainy [State and prospects of development of construction industry of Ukraine]. Haluzeve mashynobuduvannia, budivnytstvo, Vyp. 4(39), T. 2. pp. 83-89. 
2. Bohdan N.M. (2012). Teoretychni aspekty zabezpechennia ekonomichnoi bezpeky pidpryiemstv budivelnoho kompleksu v protsesi vzaiemodii iz zovnishnim seredovyshchem [Theoretical aspects of ensuring the economic security of the enterprises of the building complex in the process of interaction with the external environment]. Efektyvna ekonomika, no. 10. URL: http://www.economy.nayka.com.ua/ ?op $=1 \& \mathrm{z}=1434$ (accessed 10.09.2019).

3. Holovne upravlinnia statystyky v Dnipropetrovskii oblasti [Main Directorate of Statistics in Dnipropetrovsk Oblast]. URL: http://www.dneprstat.gov.ua/

4. Hospodarskyi kodeks Ukrainy vid 16.01.2003 № 436-IV [Commercial Code of Ukraine dated 16.01.2003 № 436-IV]. URL: http://zakon1.rada.gov.ua/laws/show/436-15

5. Hryhorieva L.V. (2012). Otsinka potentsialu budivelnykh pidpryiemstv yak analitychne zabezpechennia investuvannia [Assessment of the potential of construction companies as analytical support for investment]. Efektyvna ekonomika, no. 9. URL: http://www.economy.nayka.com.ua/?op=1\&z=1363 (accessed 10.09.2019).

6. Derzhavnyi komitet statystyky Ukrainy [State Statistics Committee of Ukraine]. URL: www.ukrstat.gov.ua

7. Ekonomika pidpryiemstva : pidruch. / za red. S. F. Pokropyvnoho. Kyiv : KNEU, 2001. 526 p.

8. Ekonomichna bezpeka / Korystin O.Ie. ta in. Kyiv : Tsentr uchbovoi literatury, 2010.368 p.

9. Zhykhor O.B., Kutsenko T.M. (2013). Ekonomichna bezpeka : navch. posib [Economic security: teach. tool]. Kharkiv : KhIBS UBS NBU, 138 p.

10. Metodychni rekomendatsii shchodo rozrakhunku rivnia ekonomichnoi bezpeky Ukrainy vid 29.10.2013 roku № 1277 / M-vo ekonomichnoho rozvytku i torhivli Ukrainy. URL: https://zakon.rada.gov.ua/rada/show/v1277731-13/stru (accessed 18.09.2019).

11. Molodid O.O. (2009). Kharakterystyka zahroz ekonomichnoi bezpeky budivelnoho pidpryiemstva [Characterization of threats to the economic security of a construction company]. Teoriia $i$ praktyka budivnytstva, no. 5, pp. 54-58.

12. Orlovska Yu.V., Fisunenko P.A., Levchenko V.F. (2013). Analiz stanu ta tendentsii rozvytku budivelnykh pidpryiemstv $u$ konteksti doslidzhennia yikh ekonomichnoi bezpeky [Analysis of the 
state and tendencies of development of construction enterprises in the context of the study of their economic security]. Teoretychni $i$ praktychni aspekty ekonomiky ta intelektualnoi vlasnosti: Zbirnyk naukovykh prats. Mariupol: DVNZ «PDTU», Vyp. 1, T. 1, pp. 248-252.

13. Safonov Yu.M., Kravets V.R., Oliukha V.H. (2014). Ekonomiko-pravovi osnovy kapitalnoho budivnytstva : navch. posib [Economic and Legal Foundations of Capital Construction: tutorial. tool]. Kyiv : Tsentr uchbovoi literatury, $239 \mathrm{p}$.

14. Fedorenko V.H., Tuhai A.M., Hoiko A.F., Dzhabeilo V.B. (2007). Kontseptsiia stratehii rozvytku budivelnoho kompleksu Ukrainy na period do 2015 roku [Concept of strategy of development of construction complex of Ukraine for the period up to 2015]. Ekonomika ta derzhava, no. 1, pp. 3-7.

15. Chorna M.V., Piriatinska I.V. (2012). Kontseptualna model ekonomichnoi bezpeky budivelnoho pidpryiemstva [Conceptual model of economic security of construction enterprise]. Efektyvna ekonomika, no. 10. URL: http://www.economy.nayka.com.ua/?op=1\&z=1477 (accessed 10.09.2019).

\section{Information about the author:}

Fisunenko P. A.

Ph.D in Economics, Associate Professor, Department of Economics and Entrepreneurship, Prydniprovs'ka State Academy of Civil Engineering and Architecture, Ukraine 